RESEARCH ARTICLE - WASPS

\title{
Division of labor in stable social hierarchy of the independent-founding wasp Mischocyt- tarus (Monocyttarus) cassununga, Von Ihering (Hymenoptera, Vespidae)
}

\author{
ASN MURAKAMI, IC DESUÓ, SN SHIMA \\ Universidade Estadual Paulista "Júlio de Mesquista Filho", UNESP, Rio Claro, SP, Brazil.
}

Article History
$\begin{array}{ll}\text { Edited by: } & \\ \text { Marcel Hermes, UFPR - Brazil } \\ \text { Received } & \text { 21 January } 2013 \\ \text { Initial acceptance } & \text { 19 February } 2013 \\ \text { Final acceptance } & \text { 22 February } 2013\end{array}$

\section{Keywords}

Social biology; dominance hierarchy; behavioral repertoire; Polistinae; Mischocyttarini.

\section{Corresponding author}

André Sunao Nishiuchi Murakami Departamento de Zoologia Instituto de Biociências, UNESP 24-A Avenue 1515, Rio Claro, SP, Brazil, 13506-900.

E-Mail: sunamigobio@yahoo.com.br

\begin{abstract}
In colonies of independent-founding wasps, social organization is characterized by a division of labor wherein the most dominant female (the queen) spends more time on the nest comb during its development, while the subordinates (workers) perform most of the foraging. The present study aimed at describing how tasks are assigned among the members of colonies of Mischocyttarus cassununga (Von Ihering) during the postemergence phase. For this, we daily tape recorded the behavioral repertoire of thirteen colonies in the field, later analyzing the results of each colonial subphase with Statistic analysis (Principal Component Analysis, Clustering Analysis and ANOVA - Tukey-Kramer t-test $\mathrm{p}<0.05)$. Our results showed that the assignment of tasks in $M$. cassununga generally reflects the dominance hierarchy. Despite of the behavioral flexibility of basal eusocial wasps (or absence of a well-defined temporal polyethism), it was possible to identify different groups of subordinate females (workers) in the colony. The division of labor during the pre-male subphase was delineated with four defined groups, whereas the post-male subphase with three groups. Pre-male: G1 - a dominant group of reproductive females, G2 - a group of higher hierarchically subordinate females (these can sometimes perform tasks very similar to the queens), G3 - a subordinate group of forager females, and G4 - a subordinate group of inactive and principally young wasps. Post-male: G1, G2 and G3 (similar to groups during pre-male subphase), but without G4. We think these analyses suggest a novel view of the importance of the behavioral repertoire of higher hierarchically subordinate females in wasp nests, at least in the genus Mischocyttarus.
\end{abstract}

\section{Introduction}

Division of labor is important to the colonial organization of social insects and the resulting castes in the colonies are basically the reproductive and the worker castes (Wilson, 1971; Naug \& Gadagkar, 1998). Most studies regarding labor distribution in these insects have focused on polyethism, i.e. the rules regulating how each individual worker is assigned to specific tasks from the whole repertoire of activities of the colony (Naug, 2001). According to Jeanne (1991), this behavioral specialization of the colony members is one of the most striking features of eusocial insects.

In independent-founding wasps there is no morphological differentiation between different castes, thus queens and workers have to be discerned by behavioral characteristics (Jeanne, 1986; Giannotti, 1992). The reproductive division of labor derives from the polygynic association among foundresses, as well as between these females and the new workers in a same colony (haplometrosis) (Jeanne, 1991). As a rule, the dominant female (queen) remains most of the time performing intranidal tasks, whereas the subordinates are mainly responsible for the foraging activities (WestEberhard, 1969; Richards, 1971; Gobbi, 1977; Torres et al., 2009, 2012). Therefore, dominance interactions take place among all members of the colony, and affect how tasks are assigned within the colony (Pardi, 1948; Jeanne, 1972; Chandrashekara \& Gadagkar, 1991; O’Donnell, 1998a, b). Moreover, in this basal group, the hierarchical position of a wasp is directly correlated with its reproductive success 
(Litte, 1977, 1981; Pratte, 1989; Chandrashekara \& Gadagkar, 1991; Tindo \& Dejean, 1998).

In the present study we aimed at evaluating polyethism in the social organization of developing colonies of the independent-founding wasp Mischocyttarus cassununga (Von Ihering) in the field, focusing on the pre-male and postmale substages of the post-emergence phase of the colony cycle.

\section{Materials and Methods}

Twelve colonies were chosen for observation on the field in order to assess the dynamics of labor division in $M$. cassununga, consequently also evaluating social regulation and organization during the ontogeny of the colonies: eight colonies undergoing pre-male subphase of post-emergence (A1, A2, A3, A4, A6, A7, A8 and A9), and four in the postmale subphase of post-emergence (B1, B2, B3 and B5). All of these colonies were located inside the university campus of UNESP, Rio Claro, SP, Brazil (22o24'26”S, 47o33'36”W).

The colonial cycle phases were determined based on the immature forms found, and by counting the number of adults in the nests. Every adult wasp was individually marked with a combination of colors (airplane modelling acrylic paint) applied over their mesoscutum, and was observed from the day of its emergence until the end of the experiment, or until it eventually disappeared from the colony. Based on this, we were able to determine the relative age of some wasps, except for those which already were in the nests when our observations began.

All behaviors in the colonies were tape-recorded with a Sony-DCR-TRV17 video camera during one hour each day, resulting in approximately 10 hours of observation per colony. The age of each female was determined from the day when the young individual emerged from the colony and in case of the females that were present at beginning of field study, the age was estimated based on the total time of observation (Pre-male subphase: \pm 100 days and Post-male subphase: \pm 50 days).

The hierarchical position of the females in each colony was determined by the frequency of the aggressive behaviors $(\mathrm{D}=$ dominance and $\mathrm{S}=$ subordination $)$ and the method of linearization ( $\mathrm{Id}=$ Dominance index) of Premnath et al. (1990).

Once a social hierarchy was determined in the colonies, we started to record the following behaviors (the frequency each individual wasp performed every behavior):

- Cell inspection (Ci): when a wasp surveys the cells for eggs, larvae, or pupae with its antennae;

- Foraging for food $(\mathrm{F})$ : when a wasp returns with food (either nectar or a macerated prey) to the nest between its mandibles and shares it with other females (frequently dominants);

- Ingesting food (IF): a part of the regurgitated material (prey) to a larva is rapidly incorporated from the crop to nourish other body regions of the adult wasps (Hunt, 1984). This happens during the provisioning behavior, when a wasp malaxates food given by another wasp, before feeding larvae;

- Feeding larvae (Fl): when the wasp inserts the head into a cell to give the malaxated prey to a larva.

In our previous studies, the behaviors that were selected had a high importance for discrimination between dominant and subordinate wasps in the colony.

All behavior variables (D, S, Ci, F, IF and Fl) were standardized for a better analysis, and then, these six components were submitted to a Principal Components Analysis (Biplot Analysis) and Clustering Analysis (Zar, 1999). The first analysis helped us to obtain the visualization and the distribution pattern (Biplot analysis) of our data, while

Table 1. Values of $\mathrm{Id}=$ Dominance index during the establishment of social hierarchy in $M$. cassununga .

\begin{tabular}{|c|c|c|c|c|c|c|c|c|c|c|c|c|c|c|}
\hline \multirow{2}{*}{$\mathrm{Sb}$} & \multirow{2}{*}{$\mathrm{Col}$} & \multicolumn{13}{|c|}{ Rank in the dominance hierarchy } \\
\hline & & $1^{\text {st }}$ & $2^{\text {nd }}$ & $3^{\text {rd }}$ & $4^{\text {th }}$ & $5^{\text {th }}$ & $6^{\text {th }}$ & $7^{\text {th }}$ & $8^{\text {th }}$ & $9^{\text {th }}$ & $10^{\text {th }}$ & $11^{\text {th }}$ & $12^{\text {th }}$ & $13^{\text {th }}$ \\
\hline \multirow{8}{*}{ A } & 1 & 1 & 0.46 & 0.41 & 0.35 & 0.14 & 0.04 & 0.03 & 0.01 & 0 & 0 & 0 & 0 & - \\
\hline & 2 & 1 & 0.42 & 0.18 & 0.08 & 0 & - & - & - & - & - & - & - & - \\
\hline & 3 & 1.05 & 0.38 & 0.18 & 0.11 & 0.07 & 0.05 & 0.02 & - & - & - & - & - & - \\
\hline & 4 & 1 & 0.22 & 0.14 & 0 & 0 & 0 & - & - & - & - & - & - & - \\
\hline & 6 & 1.04 & 0.42 & 0.24 & 0.22 & - & - & - & - & - & - & - & - & - \\
\hline & 7 & 1.02 & 0.74 & 0.37 & - & - & - & - & - & - & - & - & - & - \\
\hline & 8 & 1.07 & 0.12 & 0.50 & 0.33 & - & - & - & - & - & - & - & - & - \\
\hline & 9 & 1 & 0.50 & 0.38 & 0.22 & - & - & - & - & - & - & - & - & - \\
\hline \multirow{4}{*}{ B } & 1 & 1.09 & 0.98 & 0.88 & 0.58 & 0.51 & - & - & - & - & - & - & - & - \\
\hline & 2 & 1 & 0.30 & 0.21 & 0 & - & - & - & - & - & - & - & - & - \\
\hline & 3 & 1.02 & 0.71 & 0.55 & 0.33 & 0.18 & 0.13 & 0.04 & - & - & - & - & - & - \\
\hline & 5 & 1 & 0.60 & 0.56 & 0.41 & 0.38 & 0.12 & 0.09 & 0.07 & - & - & - & - & - \\
\hline
\end{tabular}

$\mathbf{S b}=$ Subphase; $\mathbf{A}=$ Pre-male subphase $; \mathbf{B}=$ Post-male subphase; $\mathbf{C o l}=$ Colony. $\mathbf{X}=$ hierarchical position not occupied. 
the second allowed us to identify groups of individuals that behave similarly or showed similar characteristics (Clustering analysis). Finally, we used Tukey-Kramer method with ANOVA to test the significance among all groups of individuals by comparison. The data were analysed using Statistica 8.0, Excel 14.0 and SAS softwares, according to the colony cycle (pre- or post- male subphases).

\section{Results}

\section{Dominance index and the social hierarchy in the colonies}

The study of dominance-subordinate relationship among all members from each colony resulted in a defined linear hierarchy according to dominance index (Id) (Table $1)$. It also shows that the queen is clearly the most aggressive individual in the colony of $M$. cassununga, that is, there is a direct relation between aggressiveness and position of social ranking.

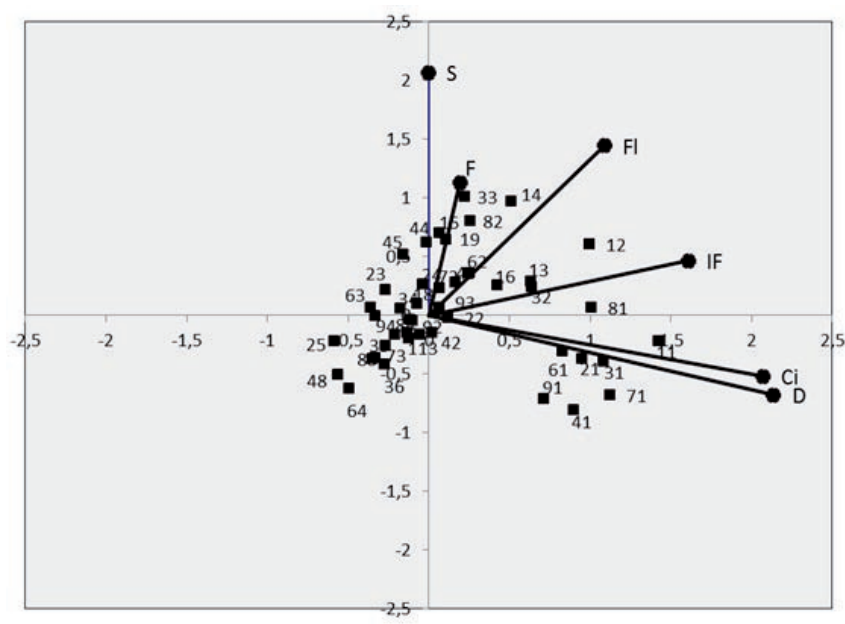

Figure 1. Principal component analysis of 6 components and the distribution of individuals from colonies A1, A2, A3, A4, A6, A7, $\mathrm{A} 8$ and $\mathrm{A} 9$ in the pre-male subphase (post-emergence phase) of $M$. cassununga in relation to vectors 1 and $2(1=$ Cell inspection and 2 $=$ Subordination).

Statistical component analysis - Division of labor during the pre-male subphase of the post-emergence phase

The principal components analysis applied during this subphase yielded three vectors that explained $87.7 \%$ of variance in the behavioral data (Table 2). Thus, the first Principal Component (PC) was most heavily weighted by individuals that inspected the content of cells and that showed high frequency of dominance, whereas the second PC was most heavily weighted by individuals that showed high frequency of subordination and that fed the larvae, and the third PC was most heavily weighted by individuals that foraged during most of the observation time (Table 2).
Table 2. Eigenvector coefficients from principal components analysis of colonies A1, A2, A3, A4, A6, A7, A8 and A9 in the pre-male subphase (post-emergence phase) of $M$. cassununga.

\begin{tabular}{lrrr}
\hline $\begin{array}{c}\text { Hierarchical position/ } \\
\text { behaviours }\end{array}$ & Vector 1 & Vector 2 & Vector 3 \\
\hline D - Dominance & 0.564 & -0.307 & 0.180 \\
S - subordination & 0.067 & 0.687 & -0.362 \\
IF - Ingesting food & 0.477 & 0.130 & -0.170 \\
Fl - Feeding larvae & 0.352 & 0.448 & -0.109 \\
F - Foraging for food & 0.041 & 0.422 & 0.892 \\
Ci - Cell inspection & 0.570 & -0.193 & 0.011 \\
& & & \\
Eigenvalues & 2.823 & 1.501 & 0.937 \\
Cumulative \% & 47.100 & 72.100 & 87.700 \\
\hline
\end{tabular}

Considering the PCA (Figure 1) and the Clustering analysis (Figure 2), it is clearly noted that, in these colonies, the dominant females $(11,21,31,41,91,61,71$ and 81) were grouped (G1) in a position distinct from all subordinates (on the right bottom side of the graph), because of the dominant characters (Figure 1): dominance (D) (=aggressiveness) and especially cell inspection (Ci). These females were also the oldest individuals in the colonies, as they were present in the nests at the beginning of the observation (Age: more than 100 days).

In addition, it is possible to differentiate the subordinates in three basic groups (G2, G3 and G4). The subordinate females of G2 $(12,13,14,15,16,24,32,33,37,43$, $44,52,62,72$ and 82 ) are generally relatively old females (Age: $72 \pm 52.21$ days) of higher hierarchical position that perform mainly on-nest tasks together with the dominant female (Figure 1: IF and Fl). However, they are constantly dominated by the dominant at high rate (as demonstrated in Table 1). In turn, the wasps of G3 $(18,19,25,34$ and 45; Age: $56.66 \pm 32.93$ days) were characterized by a more intense foraging activity in comparison to the other groups, whereas the individuals of G4 (the rest of individuals) were the youngest wasps in the nest (Age: $6.75 \pm 2.22$ days) and relatively the most inactive individuals (Figures 1 and 2).

In the pre-male subphase, the results of ANOVA significance (Tukey-Kramer t-test $\mathrm{p}<0.05$ ) showed that, through the analysed behaviors, it is possible to differentiate and group individuals into four categories in the division of labor of the colony (G1, G2, G3 and G4) (Table 3). Table 3 demonstrates the relative percentage of behaviors among defined groups (G1: reproductively dominant females; G2: other females of higher hierarchically position; G3: foragers; and G4: more inactive females).

Statistical component analysis - Division of labor during the post-male subphase of the post-emergence phase

During the post-male subphase in the post-emergence phase, the principal component analysis of colonies yielded 

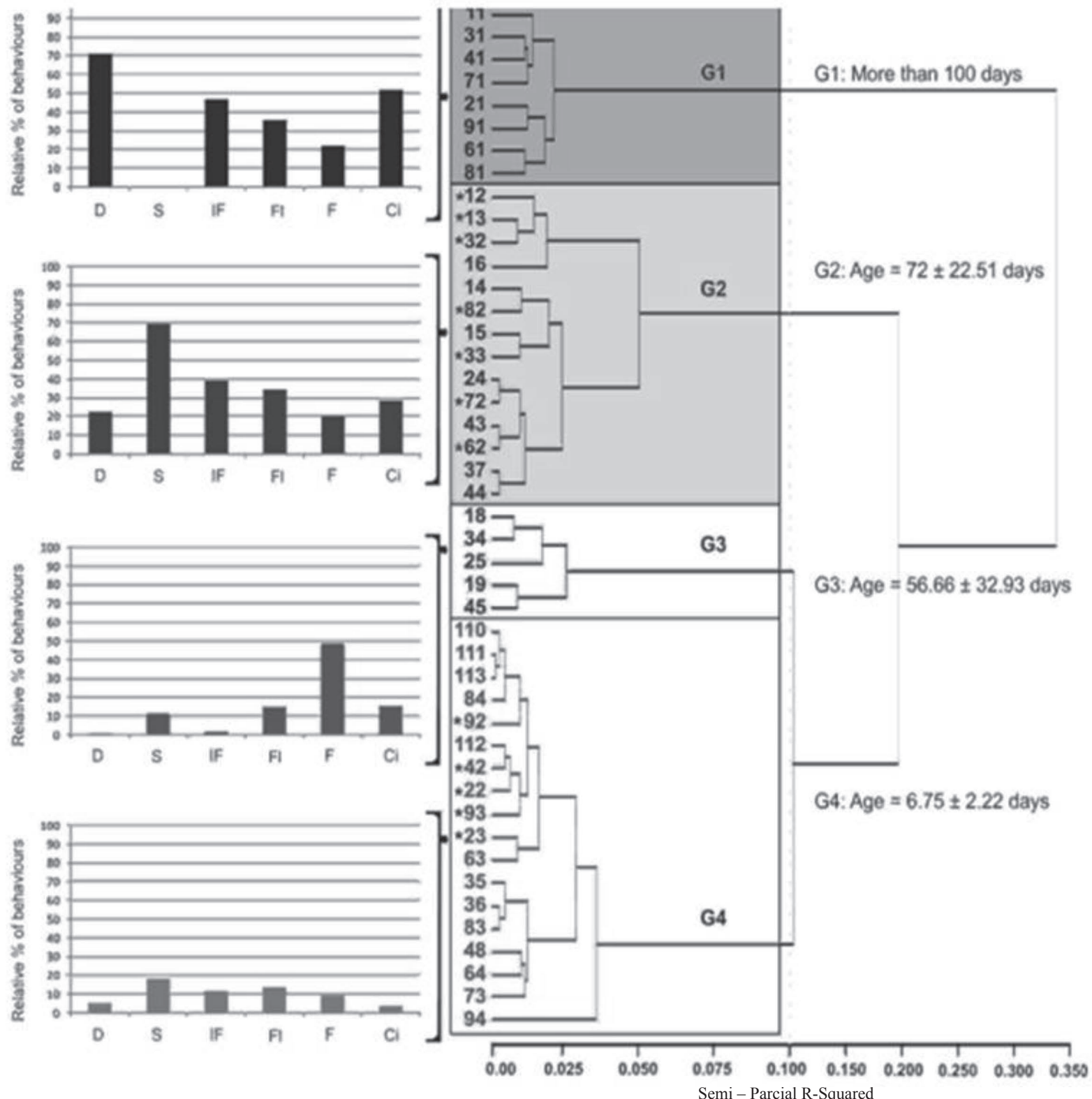

Figure 2. Hierarchical clustering analysis. Cluster of individuals from colonies in the pre-male subphase (post-emergence phase) of $M$. cassununga. Data from Fig. 1 were used. *Others individuals of undetermined age: presence at the beginning of the observation.

three vectors that together explained $86.5 \%$ of the overall variance of behaviors (Table 4). Similarly, the first Principal Component (PC) was most heavily weighted by individuals that inspected the content of cells and showed high frequency of dominance, whereas the second PC was most heavily weighted by individuals that showed high frequency of subordination and fed the larvae (Table 4). Finally, the third PC was most heavily weighted by individuals that were responsible for the foraging activity on the colonies.

According to the PCA (Figure 3) and Clustering Analysis (Figure 4), individuals of colonies during the postmale subphase can be distributed into three groups (G1, G2 and G3) (Table 5). The first group (G1) is constituted by the most dominant and the oldest females (Age: more than 50 days), whereas the second group (G2) was formed by individuals of higher hierarchical position (Age: $30.5 \pm 4.95$ days) that remain most of the time on the nest, performing tasks together with the dominant female. The third group (G3) was constituted by young subordinate females (Age: $23.75 \pm 10.21$ days) that mainly perform the foraging activity (Figures 4 and 5). A fourth group was not identified in this subphase.

In turn, in this subphase, the results (Tukey-Kramer t-test $\mathrm{p}<0.05$ ) showed that, through observing some behaviors, it is possible to differentiate and group individuals into three categories in the division of labor of the colony (G1, G2 and G3) (Table 5). According to the relative percentage of behaviors in Table 5, the defined groups are represented by $\mathrm{G} 1$ : reproductively dominant females, G2: other females of higher hierarchically position and G3: foragers. 
Table 3. Comparison among four groups derived from clustering analysis according to all behavioral categories (Means \pm Sd) in the pre-male subphase (post-emergence phase) of M. cassununga.

\begin{tabular}{|c|c|c|c|c|c|c|}
\hline \multirow{2}{*}{ Group of Females } & \multicolumn{6}{|c|}{ Means $\pm S d$ (frequency of behavior) } \\
\hline & $\mathrm{D}$ & $\mathrm{S}$ & IF & $\mathrm{Fl}$ & $\mathrm{F}$ & $\mathrm{Ci}$ \\
\hline G1 $(n=08)$ & $6.94 \pm 5.16$ & $0.03 \pm 0.09$ & $0.81 \pm 0.43$ & $2.36 \pm 2.26$ & $0.41 \pm 0.51$ & $4.47 \pm 5.04$ \\
\hline $\mathrm{G} 2(\mathrm{n}=13)$ & $2.17 \pm 2.34$ & $4.30 \pm 2.84$ & $0.68 \pm 0.50$ & $2.30 \pm 3.25$ & $0.37 \pm 0.40$ & $2.48 \pm 2.49$ \\
\hline $\mathrm{G} 3(\mathrm{n}=05)$ & $0.10 \pm 0.22$ & $0.72 \pm 0.61$ & $0.03 \pm 0.06$ & $1.00 \pm 0.61$ & $0.90 \pm 0.32$ & $1.33 \pm 0.18$ \\
\hline G4 $(n=18)$ & $0.52 \pm 0.82$ & $1.15 \pm 1.23$ & $0.21 \pm 0.24$ & $0.93 \pm 1.19$ & $0.17 \pm 0.18$ & $0.35 \pm 0.63$ \\
\hline \multicolumn{7}{|l|}{ Post-hoc comparisons } \\
\hline G1 vs G2 & * & * & ns & ns & ns & ns \\
\hline G1 vs G3 & * & * & * & ns & * & * \\
\hline G1 vs G4 & $*$ & $*$ & * & $*$ & $\mathrm{~ns}$ & $*$ \\
\hline G2 vs G3 & * & * & * & ns & * & * \\
\hline G2 vs G4 & $*$ & $*$ & $*$ & ns & $\mathrm{ns}$ & $*$ \\
\hline G3 vs G4 & ns & ns & ns & ns & * & ns \\
\hline
\end{tabular}

D - Dominance, S - Subordination, IF - Ingesting food, Fl Feeding larvae, F - Foraging for food, Ci - Cell inspection. * = ANOVA significance (Tukey-Kramer $\mathrm{t}$-test $\mathrm{p}<0.05)$, ns - no statistical significance.

Table 4. Eigenvector coefficients from principal components analysis of colonies B1, B2, B3 and B5 in the pre-male subphase (post-emergence phase) of M. cassununga.

\begin{tabular}{lccr}
\hline Hierarchical position/ behaviors & Vector 1 & Vector 2 & Vector 3 \\
\hline D - Dominance & 0.551 & -0.351 & -0.019 \\
S - Subordination & -0.104 & 0.575 & -0.433 \\
IF - Ingesting food & 0.457 & 0.370 & 0.239 \\
F1 - Feeding larvae & 0.173 & 0.542 & 0.596 \\
F - Foraging for food & -0.351 & -0.282 & 0.630 \\
Ci - Cell inspection & 0.569 & -0.191 & -0.046 \\
Eigenvalues & 3.026 & 1.245 & 0.918 \\
Cumulative $\%$ & 50.400 & 71.200 & 86.500 \\
\hline
\end{tabular}

Table 5. Comparison among three groups derived from clustering analysis according to all behavioral categories (Means \pm Sd) in the post-male subphase (post-emergence phase) of M. cassununga.

\begin{tabular}{|c|c|c|c|c|c|c|}
\hline \multirow{2}{*}{ Group of Females } & \multicolumn{6}{|c|}{ Means \pm Sd (frequency of behaviors) } \\
\hline & $\mathrm{D}$ & $\mathrm{S}$ & IF & $\mathrm{F} 1$ & $\mathrm{~F}$ & $\mathrm{Ci}$ \\
\hline G1 $(n=08)$ & $5.73 \pm 1.78$ & $0.29 \pm 0.58$ & $1.30 \pm 1.02$ & $1.53 \pm 2.10$ & $0.03 \pm 0.07$ & $4.45 \pm 5.24$ \\
\hline $\mathrm{G} 2(\mathrm{n}=13)$ & $1.83 \pm 1.27$ & $2.82 \pm 1.70$ & $1.05 \pm 0.50$ & $2.13 \pm 1.45$ & $0.13 \pm 0.14$ & $2.00 \pm 2.50$ \\
\hline G3 $(n=05)$ & $0.51 \pm 0.90$ & $1.85 \pm 1.56$ & $0.22 \pm 0.27$ & $1.45 \pm 1.50$ & $0.78 \pm 0.80$ & $0.71 \pm 0.96$ \\
\hline \multicolumn{7}{|l|}{ Post-hoc comparisons } \\
\hline G1 vs G2 & $*$ & $*$ & $\mathrm{~ns}$ & $\mathrm{~ns}$ & ns & ns \\
\hline G1 vs G3 & $*$ & $*$ & $*$ & $\mathrm{~ns}$ & $*$ & $*$ \\
\hline G2 vs G3 & * & ns & $*$ & ns & $*$ & $\mathrm{~ns}$ \\
\hline
\end{tabular}

D - Dominance, S - Subordination, IF - Ingesting food, Fl Feeding larvae, F - Foraging for food, Ci - Cell inspection. * = ANOVA significance (Tukey-Kramer t-test $\mathrm{p}<0.05$ ), ns - no statistical significance. 


\section{Discussion}

Our results illustrate that dominant females (G1) in M. cassununga tend to be distinguished from the subordinates (G2, G3 and G4 in the pre-male subphase and G2 and G3 in the post-male subphase) mainly by aggressiveness (D) and, to a less extent, by inspecting cells (Ci). These behaviors are characteristic of the reproductive dominant wasp and contribute to the social status. According to the studies of Pardi (1948) with Polistes dominulus (=gallicus) (Christ), of Jeanne (1972) with Mischocyttarus drewseni (Saussure), and of O'Donnell (1998b) and Markiewicz and O'Donnell (2001) with Mischocyttarus mastigophorus (Richards), the dominant wasp in the nests tends to avoid energy-expensive tasks (like foraging), as to invest more energy in social control and reproductive performance. The only difference between G1 and G2 is in the dominance characteristic for both subphases (Tables 3 and 5). In the genus Polistes, apart from behaviors that are typical of dominant wasps (initiating cells and oviposition), other frequent behaviours like dominance, inspecting cells and oophagy were also performed by the dominant females of the nests (Pardi, 1948; West-Eberhard, 1969; Richards, 1971; Gobbi, 1977; Torres et al., 2009).

A new interesting finding is that some females of higher hierarchical positions (G2) engaged in more on-nest activities, meaning that these females of the G2 group remain on the nest, taking care of the brood together with the dominant wasp. The results show that these females also feed the larvae (Fl), ingest food (IF) and inspect the cells (Ci) in higher frequencies (Tables 3 and 5). According to Reeve and Gamboa (1983), in nests with more females, the queens of Polistes fuscatus (Fabricius) intensify their activities and focus their attention onto some females for maintaining the reproductive monopolisation. These individuals that receive more attention by the queens occupy high hierarchical positions, thus regulating activities of other groups and having a chance to have a share in the reproductive yield of the colony. Moreover, the G2 individuals are able to lay 2n eggs (Ep), because they are inseminated, as demonstrated by Murakami and Shima (2009) for the same species of this study. Hence, we can suppose that the main reason for the wasps to spend much time in the nest would be different for these two hierarchical classes (reproductively dominant females = "queens" and females of hierarchically higher position): the queen can directly manipulate the reproductive dynamics during its stay in the nest, while the females of higher hierarchical positions can increment their nutritional reserves and, increase their reproductive potential. According to Murakami and Shima (2006), the existence of a hierarchy related to the food quantity consumed by the adult individuals of $M$. cassununga was demonstrated. Furthermore, the experimental manipulation in this study showed that adult females of hierarchically higher positions can replace the dominant wasp after her retreat. In Mischocyttarus cerberus styx (Richards), Costa-Filho et al. (2011) observed that these females in higher positions may be saving energy, which would otherwise be primarily spent on foraging trips. Thus, these individuals would have a much higher chance of assuming the position of an egg layer than a regular forager. Additionally, considering the age of these females (the second oldest individuals in the nest), our results indicate that the age is an important point during the reproductive competition inside the colony. It is more advantageous for an old female to stay on the nest and have the opportunity for reproduction or substitution of the dominant female, instead of abandoning the nest to start a new cycle of a colony.

On the other hand, the females of the G3 group are responsible for foraging for food (Ff), and consequently, also for feeding larvae after partially distribute the food for other wasps (especially for dominant wasps) on the nest (Tables 3 and 5). Thus, we considered in our study, that these females are typical foragers, and remain on the nest for less time. Regarding the behavioral repertoire of independentfounding wasps, the foraging activity is more significant for the subordinate females (Pardi, 1948; Jeanne, 1972; Giannotti, 1999; Torres et al., 2009).

Differently from the post-male subphase, a fourth group (G4) can be identified during the pre-male subphase (Table 3 and 5). This group is constituted by relatively more inactive and principally younger wasps which remain more time on the back of the nest. It may be noted that some individuals of hierarchically higher position or foragers (A2: 22 and 23; A4: 42; A9: 92 and 93) are grouped together here, and this can be explained by differences in data collection of the total frequency of behaviors observed in the same period of time (total of 10 hours). Once they perform their characteristic activities in their respective colonies, this may influence the analysis of the total frequency of each behavior for this group and lead to a misinterpretation. In the post-male

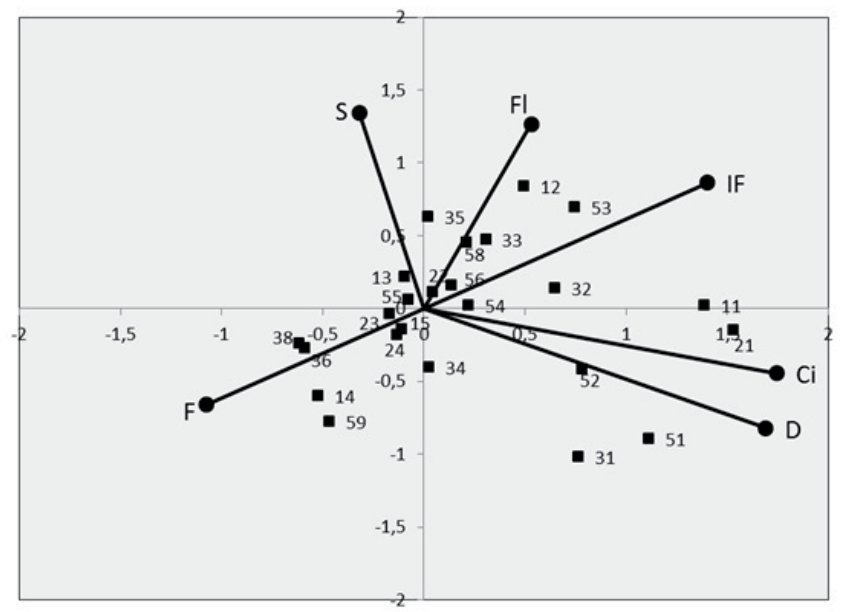

Figure 3. Principal component analysis of 6 components and the distribution of individuals from colonies A1, A2, A3, A4, A6, A7, A8 and A9 in the post-male subphase (post-emergence phase) of $M$. cassununga in relation to vectors 1 and $2(1=$ Cell inspection and 2 = Subordination). 


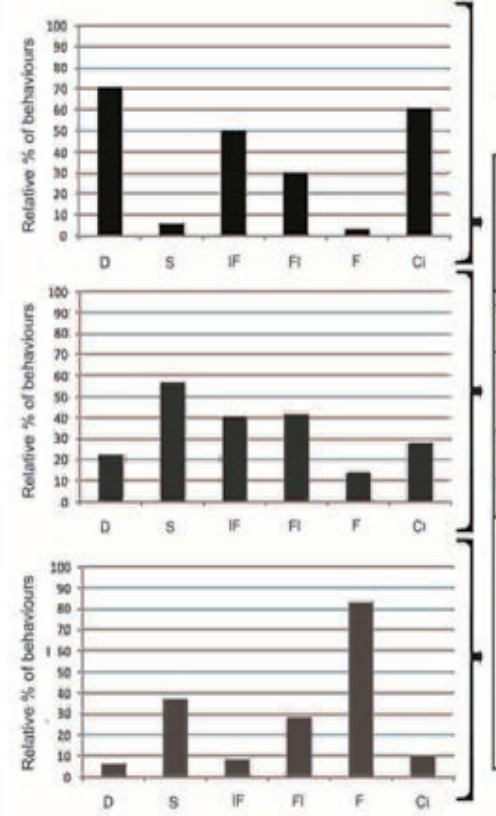

G1: More than 50 days $G 2:$ Age $=30.5 \pm 4.95$ days $G 3:$ Age $=23.75 \pm 10.21$ days
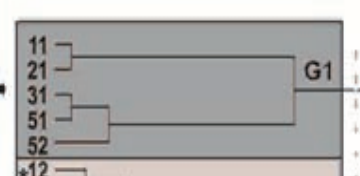

1:
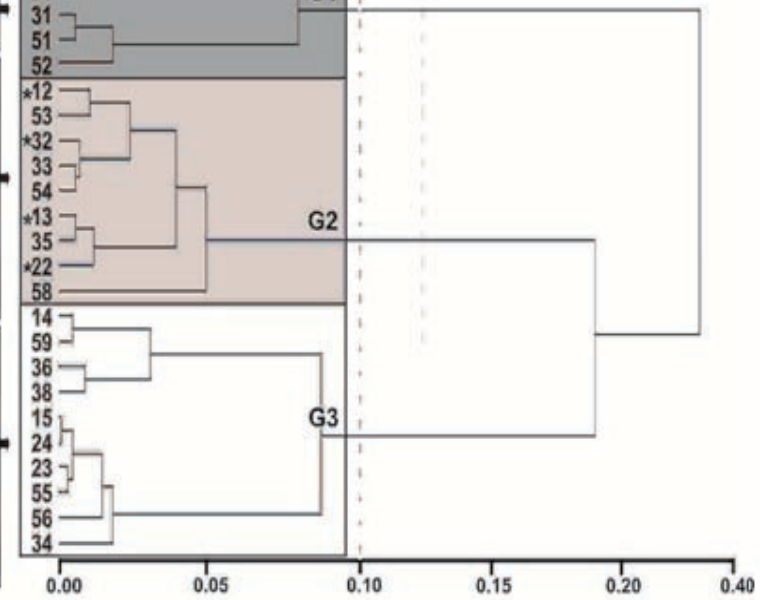

Figure 4. Hierarchical clustering analysis. Cluster of individuals from colonies in the post-male subphase (post-emergence phase) of M. cassununga. Data from Fig. 2 were used. * Others individuals of undetermined age: presence at the beginning of the observation.

subphase this group was not identified, probably by the reducing number of individuals, which is characteristic of the final period of this subphase.

Despite the flexibility of each independent wasp, some studies demonstrated that it is possible to separate the individuals of the colony in task groups. Through the PCA analysis in M. drewseni, Araújo (1980) obtained a social division in queens, intermediates, and workers that constructed new cells and foraged for food. Studying M. cerberus styx, Noda et al. (2001) demonstrated the existence of three well defined hierarchical groups in post-emergence: a dominant group composed of the three wasps of higher hierarchical positions, a neutral group including the young and the new reproductive individuals who defend the colony, and a subordinate group of lower hierarchical posts, probably all strict foragers. A similar organization was noted by Pietrobon (2005) in Polistes versicolor (Olivier) through principal components analysis, but in addition to these three groups (dominant, neutral and subordinate groups), there was another group of subordinates actively performing nearly all of the internal maintenance tasks, and responsible for expanding the colony. Based on statistical analysis (PCA, Clustering and ANOVA with Tukey-Kramer t-test), our results indicate that during the post-emergence phase, the division of labor in M. cassununga is structured, being basically defined in the groups: (G1) a dominant group of reproductive individuals; (G2) an intermediate group of females in higher hierarchical positions, which are, together with the dominant female, responsible for most internal nest tasks, and are potential substitute of the dominant wasp; (G3) a primary subordinate group constituted by typical foragers, and (G4) a secondary subordinate group composed of basically inactive and predominantly young individuals.
Concluding, the present study shows that the distribution of tasks in colonies of $M$. cassununga reflects the dominance hierarchy. Moreover, in spite of the presence of a behavioral flexibility (or absence of a well-defined temporal polyethism) in this basal eusocial wasp, it is possible to identify groups of subordinate females engaged in different functions (work) in the colony. Internal tasks performed by the dominant female (the oldest female in the colony) of $M$. cassununga are of high adaptive value, since the dominant is frequently capable of maintaining the social control during the development of the colony. Staying in the nest, laying eggs and feeding the brood with the help of females of higher hierarchical positions are bound to secure high inclusive fitness. This way, we think our analyses suggest a novel view about the importance of the behavioral repertoire of females in wasp nests, at least in the genus Mischocyttarus, which is endemic to the Americas. We think that this new scenario might explain why $M$. cassununga is characterized by a stable linear social hierarchy (Murakami \& Shima, 2010) and why dominants of this species eat more protein than the subordinates of the nest (Murakami \& Shima, 2006).

\section{Acknowledgements}

We thank Dr. Sidnei Mateus (University of São Paulo-USP) and Dr. Nivar Gobbi (São Paulo State UniversityUNESP) for their suggestions to this study, and MSc. Eduardo Fox for English language review on the manuscript. This work was supported by CNPq (National Counsel of Technological and Scientific Development). 


\section{References}

Araújo, C.Z.D. (1980). Bionomia e comportamento social comparado de Mischocyttarus drewseni de SAUSSURE 1857, nas regiões subtropical (Curitiba, PR) e tropical (Belém, PA), do Brasil (Hymenoptera, Vespidae). Master Thesis. Paraná Federal University, PR, Brazil.

Chandrashekara, K. \& Gadagkar, R. (1991). Behavioural caste, dominance and division of labor in a primitively eusocial wasp. Ethology, 87: 269-283.

Costa-Filho, V.C., Shima, S.N., Desuó, I.C. \& Murakami, A.S.N. (2011). The effects of the social hierarchy destabilization in the foraging activity of eusocial wasp Mischocyttarus cerberus styx Richards, 1940 (Hymenoptera, Vespidae, Polistinae). Psyche, 2011: 1-8. doi: 10.1155/2011/501381

Gadagkar, R. (1980). Dominance hierarchy and division of labor in the social wasp Ropalidia marginata (Lep.) (Hymenoptera: Vespidae). Curr. Sci., 49: 772-775.

Giannotti, E. (1992). Estudos biológicos e etológicos da vespa social Neotropica Polistes (Aphanilopterus) lanio lanio (FABRICIUS, 1775) (Hymenoptera, Vespidae). Ph.D. Thesis. São Paulo State University, SP, Brazil.

Giannotti, E. (1999). Social organization of eusocial wasp Mischocyttarus cerberus styx (Hymenoptera, Vespidae). Sociobiology, 33: 325-337.

Gobbi, N. (1977). Ecologia de Polistes versicolor (Hymenoptera, Vespidae). Ph.D. Thesis. São Paulo University, SP, Brazil.

Hunt, J.H. (1984). Adult nourishment during larval provisioning in a primitively eusocial wasp, Polistes metricus Say. Insectes Soc., 31: 452-460.

Jeanne, R.L. (1972). Social biology of neotropical wasp Mischocyttarus drewseni. Bull. Mus. Comp. Zool., 144(3): 63-150.

Jeanne, R.L. (1986). The evolution of the organization of work in social insects. Monit. Zool. Ital., 20: 119-133.

Jeanne, R.L. (1991). The swarm-founding Polistinae. In: Ross KG, Matthews RW (eds) The social biology of wasps. Cornell University Press, Ithaca, pp 191-231.

Litte, M. (1977). Behavioral ecology of the social wasp Mischocyttarus mexicanus. Behav. Ecol. Sociobiol., 2: 229312.

Litte, M. (1981). Social biology of the polistine wasp Mischocyttarus labiatus: survival in a Colombia rain forest. Contrib. Zool., 317: 1-26.

Markiewicz, D.A. \& O’Donnell, S. (2001). Social dominance, task performance and nutrition: implications for reproduction in eusocial wasps. J Comp Physiol A Sens Neural Behav. Physiol., 187: 327-333.
Murakami, A.S.N. \& Shima, S.N. (2006). Nutritional and social hierarchy establishment of the primitively eusocial wasp Mischocyttarus cassununga (Hymenoptera, Vespidae, Mischocyttarini) and related aspects. Sociobiology, 48: 183207.

Murakami, A.S.N. \& Shima, S.N. (2009). Queen Replacement in Mischocyttarus (Monocyttarus) cassununga (Hymenoptera, Vespidae, Mischocyttarini): a particular case. Sociobiology, 53: 247-257.

Murakami, A.S.N. \& Shima, S.N. (2010). Regulation of social hierarchy over time in colonies of the primitive eusocial wasp Mischocyttarus (Monocyttarus) cassununga. Von Ihering, 1903 (Hymenoptera, Vespidae). J. Kans. Entomol. Soc., 83(2): 163-171. doi: 10.2317/JKES0712.04.1

Naug, D. \& Gadagkar, R. (1998). Division of labor among a cohort of young individuals in a primitively eusocial wasp. Insectes Soc., 45: 247- 254.

Naug, D. (2001). Ergonomic mechanisms for handling variable amounts of work in colonies of the wasp Ropalidia marginata. Ethology, 107: 1115-1123.

Noda, S.C.M., Silva, R.E. \& Giannotti, E. (2001). Dominance hierarchy in different stages of development in colonies of the primitively eusocial wasp Mischocytarus cerberus styx (Hymenoptera, Vespidae). Sociobiology, 38: 603-614.

O’Donnell, S. (1998a). Reproductive caste determination in eusocial wasps (Hymenoptera: Vespidae). Annu. Rev. Entomol., 43: 323-346.

O'Donnell, S. (1998b). Dominance and polyethism in the eusocial wasp Mischocyttarus mastigophorus (Hymenoptera, Vespidae). Behav. Ecol. Sociobiol., 43: 327-331.

Pardi, P. (1948). Dominance order in Polistes wasps. Physiol. Zool., 21: 1-13.

Pietrobon, T.A.O. (2005). Glândula ectomandibular e comportamento de Polistes versicolor (Olivier) (Hymenoptera, Vespidae). Doctoral Thesis. São Paulo State University, SP, Brazil.

Pratte, M. (1989). Foundress association in the paper wasp Polistes dominilus Christ (Hymen. Vesp.). Effects of dominance hierarchy on the division of labor. Behaviour, 111: 208-219.

Premnath, S., Chandrashekara, K., Chandran, S. \& Gadagkar, R. (1990). Constructing dominance hierarchies in a primitively eusocial wasp. In: Veeresh G.K., Mallik B., Viraktamath C.A. (eds) Social Insects and the Environment. Proc. XI Internat. Congr. IUSSI Bangalore, Oxford \& IBH Publishing Co, New Delhi, pp 80.

Reeve, H.K. \& Gamboa, G.J. (1983). Colony activity integration in the primitively eusocial wasps: the role of the queen (Polistes fuscatus, Hymenoptera: Vespidae). Behav. 
Ecol. Sociobiol., 13: 63-74.

Richards, O.W. (1971). The biology of the social wasp (Hymenoptera, Vespidae). Biol. Rev., 46: 483-528.

Tindo, M. \& Dejean, A. (1998). Behavioral profiles related to dominance hierarchy in associated foundresses of Belonogaster juncea juncea (F.) (Hymenoptera: Vespidae). J. Insect. Behav. 11:845-852.

Torres, V.O., Antonialli-Junior W.F. \& Giannotti, E. (2009). Divisão de trabalho em colônias da vespa eussocial neotropical Polistes canadensis canadensis Linnaeus (Hymenoptera, Vespidae). Rev. Bras. Entomol. 53(4): 593-599. doi: 10.1590/ S0085-56262009000400008
Torres, V.O., Montagna, T.S., Raizer, J. \& Antonialli-Junior, W.F. (2012). Divison of labor in colonies of Mischocyttarus consimilis. J. Insect. Sci. 12(2): 1-15. doi: 10.1673/031.012.2101

West-Eberhard, M.J. (1969). The social biology of Polistine wasps. Misc. Publ. Mus. Zool. Univ. Mich., 140:1-101.

Wilson, E.O. (1971). The insect societies. Belknap Press of Harvard Univ Press, Cambridge.

Zar, H.J. (1999). Biostatistical Analysis, 4th ed. Upper Saddle River, Prentice-Hall International, New Jersey. 